\title{
Peran Public Relations dalam Komunikasi Organisasi
}

\author{
Aswad Ishak \\ Dosen Ilmu Komunikasi - Universitas Muhammadiyah Yogyakarta
}

\begin{abstract}
Abstrak
Organisasi saat ini sedang mengalami pertumbuhan dan perkembangan yang luar biasa. Perkembangan karakter publik yang semakin beragam, baik interal dan eksternal, memerlukan penanganan khusus dalam berkomunikasi dengan mereka. Kegiatan komunikasi organisasi merupakan kegiatan komunikasi strategis yang perlu dijalankan oleh organisasi. Kegiatan komunikasi ini melibatkan manajemen sebagai pengambil keputusan penting dalam organisasi. Melalui humas kegiatan komunikasi strategis organisasi dapat berjalan dengan baik. Public relations harus memiliki dukungan penuh dari manajemen untuk dapat melaksanakan tugas.
\end{abstract}

Kata kunci : komunikasi organisasi, humas, manajemen

\section{Abstract}

Organization is currently experiencing growth and remarkable development. An increasingly diverse public characters, both interal and external, require special handling in communicating to them. Communication activities of the organization is a strategic communications activities that need to be run by the organization. This communication activities involving management as important decision makers in the organization. Through public relations activities of the organization's strategic communication can run well. Public relations must have the full support of management to be able to carry out the task.

Key words : communications organizations, public relations, management

\section{Pendahuluan}

Suatu perusahaan pada saat awal didirikan sampai dengan perkembangannya kini tidak bisa dilepaskan dari proses interaksi intens yang dibangun dengan berbagai pihak. Hubungan yang dibangun di dalam organisasi tersebut, baik bersifat formal maupun informal dalam semua lapisan, pada kenyataannya memberikan pengaruh yang besar pada operasional organisasi tersebut. Interaksi yang terjadi ini tidak dapat dibatasi dalam ruang lingkup hanya sebatas komunikasi yang tejadi di dalam lingkungan organisasi. Karena pada kenyataannya pola hubungan yang terjadi di dalam organisasi pada akhirnya ditujukan pada publik di luar organisasi yang bersangkutan. Sehingga organisasi atau perusahaan berhubungan dengan publik yang berada dalam lingkungan eksternalnya secara terus menerus. Mengingat kehadiran organisasi sesungguhnya tidak hanya menyangkut kepentingan internal semata yaitu pemilik dan karyawan, namun lebih jauh kehadiran organisasi dimaksudkan guna memenuhi hajat hidup masyarakat luas yang banyak berada di luar organisasi. Di sinilah peran komunikasi internal menjadi strategis untuk dibicarakan. Hal ini karena komunikasi internal yang berjalan 
dengan baik akan memberikan kepuasan kepada seluruh publik internal. Kepuasan tersebut akan mendorong karyawan mengerjakan tugas yang diembannya dengan baik yang pada akhirnya akan menghasilkan kinerja optimal dan menghasilkan produk berkualitas dan atau pelayanan prima yang memuaskan semua publik terkait.

Komunikasi internal di dalam perusahaan biasa dikenal dengan istilah komunikasi organisasi. Terkait dengan hal ini, apabila ditinjau lebih jauh maka akan dapat ditemukan cukup banyak pandangan para ahli mengenai komunikasi organisasi. Sifat terpenting komunikasi organisasi adalah penciptaan pesan, penafsiran, dan penanganan kegiatan anggota organisasi. Bagaimana komunikasi berlangsung dalam organisasi dan apa maknanya bergantung pada konsepsi seseorang mengenai organisasi (Pace \& Faules, 1998 : 34). Dari pandangan ini nampak bahwa komunikasi organisasi dipahami sebagai kegiatan komunikasi yang berlangsung di dalam ruang lingkup organisasi. Pandangan ini tentu memiliki kebenaran sesuai dengan sudut tinjauan terjadinya komunikasi yang berlangsung. Hal ini menjadi wajar karena kebanyakan literature mengenai komunikasi organisasi mengkaji komunikasi yang terjadi di dalam organisasi itu sendiri. Namun demikian, mengingat suatu perusahaan hidup dan berkembang di tengah masayarakat (publik eksternal), maka menjadi suatu keharusan bahwa perusahaan tersebut dapat berkomunikasi dengan lingkungan eksternalnya jika ingin berhasil dalam usahanya. Hal ini disebabkan publik eksternal juga memiliki pengaruh kuat terhadap kinerja suatu organisasi melalui penilaian atau opini yang berkembang yang akan mempengaruhi pada tingkat penerimaan kehadiran perusahaan beserta seluruh produk yang dihasilkannya. Sehingga komunikasi organisasi yang semula hanya dimaknai dalam artian sempit sebagai komunikasi internal perusahaan - karena perkembangan waktu dan keterkaitan dengan hal lain- menjadi penting untuk dipahami secara lebih luas lagi. Dengan demikian komunikasi organisasi perlu dimaknai sebagai komunikasi yang dijalankan perusahaan - baik itu internal atau eksternal- dalam mencapai goal attainment yang dicitacitakan. (Grunig, 1992).

Organisasi, baik itu kecil, sedang, besar pada dasarnya akan selalu membutuhkan sentuhan komunikasi aktif guna menumbuhkan partisipasi publik dalam pengembangan operasional perusahaan. Pengelolaan aktivitas komunikasi ini menjadi sebuah keharusan dilakukan oleh praktisi komunikasi (communication specialist). Bagian atau lembaga di dalam perusahaan yang seringkali ditugaskan untuk mengelola aktivitas komunikasi tersebut adalah bagian public relations. Segala aktivitas komunikasi yang dijalankan organisasi merupakan bidang tugas dari bagian public relations, walaupun mungkin dalam tataran prakteknya public relations akan melakukan koordinasi dan kerjasama dengan bagian lain dalam organisasi guna menjalankan aktifitas komunikasi untuk mencapai tujuan yang telah ditetapkan. Dalam pengertian ini penekanannya bahwa public relations sebenarnya merupakan satu bagian penting dalam organisasi yang mengelola dan bertanggung jawab terhadap keberhasilan dan kegagalan tindakan komunikasi dari organisasi yang bersangkutan. 


\section{Pembahasan}

Mencermati kondisi riil yang ada, maka terdapat permasalahan yang patut dikaji lebih lanjut menyangkut public relations dalam suatu organisasi yaitu seperti apa praktek public relations yang dibutuhkan oleh suatu perusahaan atau organisasi. Dengan kata lain bagaimana suatu organisasi memanfaatkan public relations dalam menjalankan komunikasi organisasinya.

\section{Kondisi organisasi}

Setiap organisasi lahir, tumbuh, dan berkembang menuju apa yang dicitacitakan sesuai dengan visi misi yang telah ditetapkan. Perkembangan dan daur hidup antara satu organisasi dengan yang lain menunjukkan perbedaan. Besar kecilnya suatu perusahaan (scope) merupakan salah satu faktor yang menjadikan perbedaan tersebut menjadi nyata. Kecenderungan yang ada, semakin besar suatu organisasi akan memerlukan dan memiliki jumlah karyawan yang semakin banyak. Hal ini karena semakin banyak bidang kerja dan yang harus dilakukan. Sedangkan kemampuan seorang karyawan tentu memiliki keterbatasan dalam melaksanakan tugas secara keseluruhan. Oleh karenanya dibutuhkan lebih banyak tenaga kerja untuk menyelesaikannya. Demikian pula halnya dengan semakin besar suatu perusahaan maka kompleksitas teknologi yang digunakan juga semakin tinggi. Pada umumnya, organisasi yang besar akan membutuhkan bantuan perangkat teknologi yang jauh lebih banyak dan kompleks untuk menangani segala pekerjaan secara cepat dan membutuhkan ketepatan yang tinggi. Karena perbedaan tersebut, masing-masing perusahaan akan tidak sama dalam menerapkan sistem kerja yang dioperasionalkan. Komunikasi yang didesain dan dijalankan oleh tiap organisasi akan berbeda baik dalam model, media, maupun hasil yang dapat dicapai. Pola interaksi secara sistemik yang berlangsung secara terus menerus ini akan menjadi sebuah model komunikasi yang dijalankan yang pada akhirnya akan melahirkan terbentuknya suatu budaya perusahaan (corporate culture) yang mengakar kuat di tengah oraganisasi tersebut.

Dalam kaitan budaya perusahaan ini ada banyak budaya yang muncul. Namun demikian, bila dicermati lebih jauh dan dikelompokkan sesuai dengan kesamaan-kesamaan kecenderungan yang ada maka pada dasarnya budaya perusahaan terbagi ke dalam dua kelompok besar yang dominan muncul, yakni organisasi dengan budaya authoritarian dengan organisasi yang memiliki budaya participative. Pada perusahaan yang menganut authoritarian, budaya yang berkembang ditandai dengan sifat tertutup. Dalam model budaya ini, organisasi akan cenderung menutup akses informasi yang dimiliki baik keluar maupun kedalam organisasi (information blocking). Sehingga proes pertukaran informasi dan adaptasi antara organisasi dengan lingkungannya banyak mengalami hambatan dan perubahan yang terjadi cenderung lambat. Model komunikasi yang diterapkan dalam budaya ini bersifat asimetris yang mana yakni dominan dari organisasi kepada publiknya. Sedangkan model budaya yang kedua perusahaan yang menganut sistem participative, mereka justru akan membuka akses informasi kepada segenap publik yang terkait. Model komunikasi yang diterapkan umumnya two-way symetrical. Dengan demikian, komunikasi yang dijalankan lebih egaliter dan mampu menumbuhkan motivasi pada publik untuk merasa ikut terlibat dalam pencapaian prestasi 
keberhasilan organisasi menggapai tujuannya. Komunikasi menduduki peran penting dalam proses organisasi yang berlangsung

Masing-masing perusahaan jelas memiliki ciri spesifik tersendiri yang khas serta membedakan satu dengan yang lainnya. Bahkan dalam perusahaan yang sama besar sekalipun, dalam bidang kerja yang sama, kemungkinan kesamaan pola komunikasi organisasinya menjadi kecil. Dari uraian ringkas ini dapat diketahui bahwa setiap organisasi disadari atau tidak, memerlukan komunikasi guna membangun dan mewujudkan "blue print" perusahaan yang telah disusun. Sedangkan sejauhmana atau komunikasi organisasi seperti apa yang hendak dijalankan pada prinsipnya lebih didasari dan didorong oleh tingkat kebutuhan komunikasi dan output yang hendak diraih perusahaan tersebut. Komunikasi menjadi jembatan penting yang tidak bisa diabaikan.

\section{Aliran Informasi dalam Komunikasi Organisasi}

Dalam komunikasi yang menjadi pusat perhatian (central point) adalah persoalan informasi yang diolah dan disebarluaskan. Informasi inilah yang sesungguhnya dikomunikasikan ke segenap publik dari organisasi yang bersangkutan. Pace \& Faules (1998) menyebutkan ada beberapa model proses transfer informasi dalam komunikasi organisasi. Model yang dominan muncul adalah top-down, bottom-up, horisontal, dan lintas saluran. Keempat model tersebut berlaku bagi komunikasi internal dalam suatu perusahaan.

Pola top-down sesuai dengan namanya menunjukkan arah aliran informasi yang dijalankan vertikal ke bawah. Dalam model ini, para pimpinan memberikan informasi kepada bawahannya. Umumnya isi informasi berupa perintah berkaitan dengan penyelesaian pekerjaan yang harus dilakukan oleh staf atau karyawan. Pada pelaksanaan pola komunikasi ini hampir tidak ditemukan ada isi informasi selain terkait dengan tugas. Karyawan dan staf kurang memiliki insiatif dalam menjalankan tugas karena lebih menunggu kesesuaian dengan pesan dari atasan. Sehingga komunikasi yang dijalankan bersifat job oriented. Berbeda dengan top down, pada pola bottom-up, bawahan mengkomunikasikan maksud/ ide/gagasan/konsep yang dimiliki ke atasan. Kondisi demikian menunjukkan pula model komunikasi vertikal. Permasalahan yang sering muncul kemudian, kapan suatu kejadian itu bisa dikategorikan mengikuti pola top-down dan kapan bottom-up. Hal ini hanya bisa dijawab dari sudut pandang mana orang mulai mengamati. Sulitnya mencari jawaban ini disebabkan dalam tataran prakteknya antara top-down dan bottomup seringkali saling merespon sehingga terjadi suatu perputaran (siklus) yang tak terlalu jelas ujung pangkalnya.

Tipe aliran informasi lain yang acapkali dipraktekkan yakni komunikasi horizontal. Pada model komunikasi ini dilaksanakan oleh orang pada level yang sama pada bagian tertentu dalam perusahaan. Misal staf bagian pemasaran berhubungan dengan staf bagian promosi pada departemen pemasaran dan komunikasi. Umumnya komunikasi tipe ini digunakan untuk melakukan koordinasi pelaksanaan pekerjaan. Kemudian model lain dalam komunikasi organisasi yang dikenal sebagai model lintas saluran. Dalam model komunikasi ini bisa menembus batas posisi dimana seseorang berada. Dengan model ini anggota organisasi bisa berhubungan secara vertikal ataupun horisontal dengan 
bagian lain di dalam organisasi. Hal ini dilakukan karena banyak pekerjaan yang harus dilakukan selalu terkait dengan bagian lain di dalam organisasi. Misalkan bagian pemasaran dan promosi akan terkait dengan bagian produksi. Model aliran informasi yang terakhir ini menghasilakn sinergi dan keterpaduan rencana dan tindakan secara keseluruhan di dalam organisasi.

Penerapan model komunikasi dan arah aliran informasinya dalam organisasi perlu memperhatikan apakah bersifat simetris (two-way traffic) ataupun asimetris (one-way traffic), hal ini akan terkait erat dengan budaya perusahaan yang dianut dan berkembang. Perusahaan dengan budaya yang tertutup tentunya akan mengeliminir semaksimal mungkin komunikasi yang sifatnya bottom-up, atau bahkan akan menutup sepenuhnya partisipasi anggota organisasi dalam halhal kecil sampai dengan pengambilan keputusan. Sehingga yang tampak dominan muncul adalah pola komunikasi top-down.

Sebagaimana disebutkan di awal tulisan ini, bahwa komunikasi organisasi tidak semata-mata persoalan komunikasi internal karena pada akhirnya akan terkait dengan komunikasi eksternal. Sedangkan komunikasi organisasi yang ditujukan untuk keperluan komunikasi eksternal, tidak mengikuti pola seperti halnya dalam komunikasi internal. Model komunikasi yang dijalankan cenderung akan menyesuaikan dengan publik eksternal mana yang akan dituju, sebagai pemangku kepentingan. Hal sering teridentifikasi kemunculannya adalah model komunikasi dua arah yang bersifat dialogis. Hal ini terjadi mengingat tujuan komunikasi organisasi keluar adalah dapat tercapainya penerimaan publik atas kinerja perusahaan. Di sini reputasi perusahaan menjadi tujuan akhirnya.
Tidak lagi sekedar produk atau jasa yang telah dihasilkan laku terjual dan digunakan oleh banyak pihak.

Dari pola komunikasi seperti yang telah diuraikan pada pembahasan di atas tersebut, sebenarnya pada prinsipnya kesemua itu merupakan sarana dari pihak manajemen perusahaan atau organisasi untuk mentransfer dan mendelegasikan tugas sekaligus menangkap respons yang muncul berkaitan dengan kondisi organisasi secara keseluruhan. Hal itu berlaku baik untuk publik eksternal maupun internal organisasi. Harapanynya dengan adanya komunikasi tersebut, semua pihak dapat memahami kondisi yang berlangsung dalam perusahaan dan menjalankan aktifitas sesuai bidangnya dalam rangka mencapai keberhasilan perusahaan. Hal ini sebagaimana diungkap Bordow dan More yang menyatakan bahwa : "Just management uses communication as a tool to get the job done, the organization as an entity similiarity communicates to get specific message(s) about it self across to its diverse publics" (Bordow \& More, 1991 : 114).

\section{Peran Public Relations dalam Komu- nikasi Organisasi}

Sebagaimana telah dipaparkan sebelumnya, bahwa dalam memahami komunikasi organisasi tidak cukup hanya dilihat dari aktivitas komunikasi internal yang berlangsung. Maka komunikasi organisasi perlu dipahami dari dua sisi sekaligus : internal dan external communication. Sinyalemen tentang pentingnya komunikasi eksternal dan internal pada organisasi ini seperti dikatakan Bordow dan More bahwa :

The managers maintain communication relationship with three groups : superiors (directors or trustees, in the case of chief executives), outsiders (to the unit that he manages), and subordinate. In 
effect, he (the managers) stands between subordinates and the other, linking them in a variety of ways. (Bordow \& More, $1991: 23)$

Tujuan dari dijalankannya komunikasi organisasi adalah agar perusahaan dapat menyampaikan maksud dan kebijakan kepada segenap publik yang dimiliki (eksternal dan internal), sekaligus menyerap respons dan menindaklanjuti dalam waktu mendatang guna memperoleh penyesuaian-penyesuaian dengan lingkungannya. Tentu saja, perusahaan sulit untuk berkembang dengan baik jika tidak menjalin komunikasi dengan publiknya. Aktivitas komunikasi ini harus dikelola dengan tepat. Untuk dapat melaksanakan hal tersebut maka public relations departement merupakan bagian yang tepat guna mengelolanya. Public relations merupakan suatu "management of communication between an organization and its public" (Grunig \& Hunt, 1984 : 6). Jelaslah bahwa public relations merupakan bagian penting dalam organisasi yang menangani tindakan komunikasi antara perusahaan dengan publik yang ada.

Melalui public relations inilah manajemen organisasi melakukan aktivitas komunikasinya, baik itu kepada publik internal seperti karyawan, manajemen dan publik eksternal seperti masyarakat sekitar dan konsumen. Segala macam informasi yang menyangkut keberadaan dan operasinal organisasi, arus keluar masuknya melalui public relations. Dalam kaitan ini public relations dipandang memiliki fungsi vital sebagai suatu jembatan (bridge) antara organisasi dengan publik. Dari public relations inilah manajemen dapat menerima dan mengolah informasi yang ada untuk kemudian mengambilan keputusan strategis dalam rangka mengembangkan perusahaan. Dalam kaitan ini Garry L.
Kreps berpandangan :

Leaders need information about organizational activities to direct succesfully innovation and accomplish systemwide organizational development. Public relations efforts can provide leaders with relevant information about environmental constraints and internal organizational issues for use in guiding organizational adaptation. (Kreps, 1989 :265)

Untuk menjadikan komunikasi mampu berjalan dengan baik sesuai dengan yang diharapkan oleh organisasi, maka public relations harus dapat mengendalikan jalannya informasi yang masuk dan keluar organisasi. Informasi perlu ditata dan dikelola dengan tepat. Tanpa pengelolaan secara tepat maka komunikasi organisasi dari perusahaan yang bersangkutan akan salah arah dan salah sasaran. Permasalahan komunikasi yang baik ini Lindeborg berpandangan bahwa, "Excellent communication is communication that managed strategically, meets its objectives, and balances the needs of the organization and the need of key publics with two-way symetrical communication" (Lindeborg, 1994 : 5).

Adapun cara yang dapat ditempuh dalam menjalankan komunikasi organisasi ini beragam. Misalkan saja perusahaan dapat melakukan pertemuan rutin setiap satu bulan sekali dengan para karyawan semua lapisan, melakukan angket atau polling untuk mengetahui tingkatpemahamandankepentinganserta harapan-harapan publik atas kebijakan perusahaan, analisis isi media massa menyangkut informasi yang berkembang dan berkaitan dengan perkembangan organisasi, dan sebagainya. Tentu saja apa yang dilakukan oleh praktisi public relations tersebut harus didasarkan pada kesesuaian antara tingkat kebutuhan yang diharapkan dan kemampuan 
sumber daya yang dimiliki.

Dalam prakteknya public relations di organisasi umumnya dapat dijumpai terbagi ke dalam dua bagian yang menjalankan fungsi dasar sama namun berbeda dalam hal publik yang dituju. Kedua bagian itu adalah internal public relations dan exsternal public relations. Internal public relations mengkhususkan pada bagaimana organisasi mampu berkomunikasi secara tepat berkaitan dengan publik yang ada di dalam organsasi tersebut. Komunikasi model inilah yang sering menjadi acuan pemahaman tentang komunikasi organisasi (artian sempit). Sedangkan external public relations merupakan bagian yang menangani permasalahan komunikasi berhubungan dengan publik di luar organisasi. Ketika orang berbicara komunikasi organisasi dalam arti sempit maka yang diperoleh hanyalah gambaran bagaimana komunikasi dijalankan dalam suatu unit organisasi. Padahal, komunikasi organisasi tidak hanya komunikasi ke dalam semata, namun meliputi pula komunikasi keluar. Sehingga pemahaman mengenai komunikasi organisasi secara konkrit dapat diperoleh melalui pemahaman dalam arti luas, yang mana dalam pengertian tersebut meliputi komunikasi yang terjadi secara intern dan ekstern.

Terlepas dari artian mana yang hendak dirujuk dalam menjelaskan fenomena komunikasi organisasi, yang pasti public relations merupakan bagian yang tidak bisa dipisahkan dalam kegiatan komunikasi suatu perusahaan. Sekalipun, mungkin dalam pelaksanaannya bagian public relations tidak menutup kemungkinan bisa saja bekerjasama dengan bagian lain di dalam organisasi seperti bagian personalia, pemasaran, accounting, dan sebagainya. Public relations merupakan bagian penting dalam organisasi sebagaimana dikemukakan Kreps bahwa, "Public relations communication is an essential tool leaders utilize to gather information from organization members and other relevant publics" (Kreps, 1989 : 267).

Permasalahan yang sering muncul kemudian adalah, mengapa organisasi yang satu berbeda penerapan public relations dalam menangani komunikasi dengan yang lain. Apabila dicermati lebih mendalam, seringkali ditemukan di banyak perusahaan, public relations tidak dapat berjalan sebagaimana mestinya. Sehingga banyak orang yang meremehkan dan mengesampingkan peran strategis public relations. Bahkan tak jarang menganggap public relations hanya sebagai pelengkap dan pajangan serta pemanis perusahaan semata. Kondisi tersebut menjadikan seakanakan public relations tidak mampu berbuat apa-apa bagi perusahaan. Kerancuan ini sebenarnya tidak perlu terjadi, apabila manajemen organisasi memiliki pemahaman yang cukup bagi terwujudnya public relations yang prima (excellence) dalam menangani komunikasi organisasi. Pemahaman manajemen organisasi tersebut harus dibarengi pula dengan dukungan bagi diwujudkannya bagian public relations yang handal dalam menangani permasalahan komunikasi yang dihadapi organisasi.

Public relations dalam prakteknya dewasa ini tidak bisa lagi hanya dipahami sebagai suatu tindakan kelembagaan. Artinya public relations dilakukan oleh lembaga dengan ada bagian yang mengelola secara profesional. Lebih jauh sesungguhnya public relations merupakan suatu pendekatan yang perlu dijalankan oleh perusahaan dalam setiap langkah kebijakan yang diambil. Public relations merupakan tanggung jawab setiap anggota organisasi. Sehingga 
setiap anggota organisasi sebenarnya merupakan seorang "praktisi" public relations bagi organisasinya. Sehingga pemaknaan atas public relations seperti ini akan memberikan kontribusi yang besar bagi pengembangan organisasi dan public relations itu sendiri.

\section{Penutup}

Dalam tulisan singkat ini dapat dijelaskan bahwa komunikasi organisasi haruslah dipahami sebagai suatu komunikasi yang dijalankan organisasi kepada segenap publik yang dimiliki. Komunikasi organisasi perlu ditangani oleh bagian yang khusus bertugas mengelola aktivitas komunikasi, dalam kaitan ini public relations merupakan jawaban yang tepat. Hal ini agar tidak terjadi overlaping tugas dengan bagian lain dalam organisasi.

Public relations perlu membekali diri dengan kemampuan yang handal guna mewujudkan komunikasi yang prima (excellence). Pemahaman bahwa public relations hanya sekadar wanita cantik yang sekedar jual tampang dan sebagai pajangan perusahaan harus segera diakhiri dan dengan dukungan sepenuhnya dari manajemen melalui penerapan public relations yang kritis terhadap perkembangan jaman khususnya permasalahan komunikasi yang dihadapi.

Yang dimaksudkan komunikasi organisasi tidak bisa hanya dipahami sebatas tindakan kelembagaan (state of being) namun harus dipahami pula sebagai suatu cara atau pendekatan atau fungsi komunikasi (methode of communication). Sehingga sekalipun bagian yang menangani aktifitas komunikasi organisasi bukanlah bagian public relations, namun menggunakan atau mengedepankan fungsi atau pendekatan public relations maka harus dipahami sebagai tindakan public relations.

\section{Daftar Pustaka}

Bordow, Allan \& More, Elizabeth (1991). Managing Organizational Communication, Longman Cheshire, Australia.

Dozier, David M., Grunig, Larissa A., \& Grunig, J.E. (1995). Manager's Guide to Excellence in Public Relations and Communication Management, Lawrence Erlbaum Associates, Mahwah, New Jersey.

Grunig, J.E. (1992). 'Communication, Public Relations, and Effecive Organizations : An Overview of The Book'. dalam Grunig, J.E. (penyunting), Excellence in Public Relations and Communication Management, Hillsdale, N.J., Lawrence Erlbaum. Hal. 1-28.

Grunig, J.E. \& Hunt, T. (1984). Managing Public Relations, New York: Holt, Rinehart \& Winston.

Kreps, Garry L. (1989). 'Reflexivity and Internal Public Relations : The Role of Information in Directing Organizational Development.' dalam Botan, Carl H. \& Hazleton Jr., Vincent (penyunting), Public Relations Theory, Lawrence Erlbaum Associates Inc., New Jersey. Hal 265279.

Lindeborg, Richard A. (1994). 'Excellent Communication', Pulic Relations Quarterly Vol. 39 (1), Spring edition.

Effendy, Onong U. (1983). Human Relations dan Public Relations dalam Management, Alumni, Bandung.

Pace, R. Wayne \& Faules, Don F. (1998). Komunikasi Organisasi : Strategi Meningkatkan Kinerja Perusahaan, Remaja Rosdakarya, Bandung. 